\title{
An Evangelical/Pentecostal Approach to Interfaith Education for Seminarians and University Students
}

\author{
Tony Richie
}

\begin{abstract}
The focus of this chapter is on innovative efforts to educate Evangelical/Pentecostal seminarians and university students regarding interfaith (i.e. multifaith) understanding, dialogue, and cooperation. Most of these efforts have been conducted at the Pentecostal Theological Seminary (PTS) with related activities at Lee University. Both institutions are located in Cleveland, Tennessee, as educational ministries of the Church of God, which has international offices in Cleveland as well. ${ }^{1}$ Additionally, annual academic conferences and publications of the Society for Pentecostal Studies have provided a broader forum for promoting multifaith understanding, dialogue, and cooperation among member institutions with their respective scholars. ${ }^{2}$

The structure of this chapter is threefold. First, I outline the philosophy behind an explicitly Pentecostal pedagogy for teaching on interfaith topics in higher education contexts. Second, I survey the current state of the Christian theology of religions among Pentecostal thinkers and practitioners. The third section recounts specific educational praxis through classroom instruction and guided encounters. I discuss symbiotic concerns and questions as they arise in each section.
\end{abstract}

1 The Church of God describes itself as Christian, Protestant, Evangelical, Pentecostal, etc. "Beliefs," Church of God, last accessed October 10, 2019, http://www.churchofgod.org/beliefs/ church-of-god-is.

2 See the website of The Society for Pentecostal Studies, accessed October 10, 2019, www.spsusa.org. In my roles as Ecumenical Studies Interest Group Leader (2008-2014) and Liaison for the Society for Pentecostal Studies to the Interfaith Relations Commission of the National Council of Churches, USA (2003 to present) I have facilitated discussions on interfaith theological education. 


\section{Pedagogical Orientation: Transformational Philosophy of Christian Education on Interfaith Issues}

Pentecostals have admittedly had somewhat push-pull/love-hate attitudes toward theological education. ${ }^{3}$ Yet Pentecostalism is not inherently antiintellectual. ${ }^{4}$ Pentecostals are not only "people of the Spirit" but also "people of the Book" (viz., the Bible). ${ }^{5}$ Pentecostals thus generally recognize the importance of education - though perhaps without completely trusting it. ${ }^{6}$ Accordingly, Pentecostals have founded numerous Bible schools, colleges, universities, and seminaries, but they continue to be cautious about the inroads (real or imagined) of arid rationalism. While ambivalence toward education, or even open suspicion, persists, many Pentecostals are not opposed to education in itself, only education that destroys faith or reduces dependence on the Holy Spirit. ${ }^{7}$ There is wonderful potential for religious education that is consistent with Pentecostal faith and values while genuinely engaging the life of the mind. ${ }^{8}$

Quite obviously, theological education has a distinctive purpose and shape, and Pentecostal theological education has its own unique nature as well. This section looks at theological education as an environment for interfaith

3 Among other factors, a keen sense of eschatological urgency lends itself more readily to evangelism than education. Cf. D. William Faupel, The Everlasting Gospel: The Significance of Eschatology in the Development of Pentecostal Thought, Journal of Pentecostal Theology Supplemental Series 10 (Sheffield, UK: Sheffield Academic Press, 1996. Reprint, Dorset, UK: Deo Publishing, 2009), 307-309.

4 Noteworthy is a general populist tendency toward anti-intellectualism in America, influenced in part (e.g., after McCarthyism) by Evangelicalism and Revivalism; see Richard Hofstadter, Anti-Intellectualism in American Life (Toronto: Random House, 1962, 1963), 15, 21-22, 47.

5 French L. Arrington, Christian Doctrine: A Pentecostal Perspective, 3 vols. (Cleveland, TN: Pathway Press, 1993), 1: 25 .

6 Some suspicion may be in order. For example, R. S. Sugirtharajah, a Sri Lankan theologian educated in India, argues in The Bible and the Third World: Precolonial, Colonial and Postcolonial Encounters (Cambridge: Cambridge University Press, 2001) that Western European intellectual and philosophical resources were recruited to sustain racial biases as part of a colonialist agenda.

7 Lewis F. Wilson, "Bible Institutes, Colleges, Universities," in Stanley M. Burgess and Eduard M. Van Der Maas, eds., The New International Dictionary of Pentecostal Charismatic Movements (Grand Rapids, MI: Zondervan, 2002), 372-73; cf. Cecil M. Robeck, "Seminaries and Graduate Schools," The New International Dictionary, 1045-1050.

8 Richard Mouw is a treasure on the topic of integrating authentic scholarship with devout piety; see Called to the Life of the Mind: Some Advice for Evangelical Scholars (Grand Rapids, MI: Eerdmans, 2014). Many Pentecostals take advantage of educational opportunities in "Pentecostal-friendly" Evangelical institutions, Robeck, "Seminaries and Graduate Schools," 1050 . 
instruction and activism, beginning with a brief overview of a few basic but important guiding philosophical principles. The works of Pentecostal scholars Jackie David Johns and Cheryl Bridges Johns are helpful for comprehending an intentionally Pentecostal orientation to Christian education.

My personal testimony describes an irregular or uneven journey into theological education. Significantly, during a time of pain and anger in the immediate aftermath of 9/11, an internet chat with an African American Muslim imam inspired me to pursue theological education as a means of reaching a coherent and consistent Christian understanding of religious others and their place in the world of religions. I sensed this imam's intense pain and anger at what he saw as the hijacking of his holy faith, and I began to wrestle with personal biases and presuppositions. Interestingly, my desire to understand religious others drove me deeper into my own Christian faith. Eventually I recognized that interfaith theological education is a remarkable aid in the process of discovering our perceptions of religious others. Subsequently, theological education has become a medium for sharing the ongoing fruits of that journey within my own tradition.

Since Friedrich Schleiermacher, the purpose of theological education has often been described as an effort specific to a particular community with its various needs for nurture and leadership. ${ }^{9}$ Post-Enlightenment theological educators created an uneasy tension between theological education as a purely academic exercise and practical vocational training.

This tension frequently expresses itself in one of two ways. First, an emphasis on scholarship to the diminishment or exclusion of pastoral and/or practical ministry can result in the actual or perceived irrelevance of ministry. Second, a focus on performance of pastoral and/or practical ministry apart from sustained scholarship can result in theological inconsistencies and vulnerabilities. In either case, a divorce occurs between church and academy.

Despite perennial tensions between theory and practice, or in relating study to vocation, the value of theological education for ministry appears incontestable. Theological education, when done well, enables and equips ministers and pastors and teachers to be more effective in their Christian walk of faith, as well as helping them serve others through excellence in the thought and praxis of vocational calling. The works of Jackie and Cheryl Johns are helpful here in articulating the transformative aspects of theological education, signaling the emergence of an explicitly Pentecostal educational philosophy for realizing the goals of Pentecostal ministry, spirituality, and theology.

9 Friedrich Schleiermacher, Brief Outline of the Study of Theology (Edinburgh: T \& T Clark, 1850). 
In The Pedagogy of the Holy Spirit Jackie Johns conducts an in-depth study of the pedagogical role of the Holy Spirit in the patristic church, with specific recommendations for a contemporary paradigm of Christian education in Pentecostal contexts. ${ }^{10}$ The supervisory and participatory role of the Holy Spirit in all Christian education via "the redemptive acts of regeneration and sanctification" is central. ${ }^{11}$ Christian education is not merely for informational or vocational (i.e., ministerial) purposes, but aims at ultimate union with God through "behavioral, cognitive, volitional, and spiritual objectives which reflect the process of redemption."12 Human beings are created in God's image; acts of instruction and learning must be adapted to their abilities and needs as such. The content of Spirit-guided teaching and Spirit-enabled learning includes Scripture, both in terms of information about Jesus Christ and as a means of communion with God-particularly through affective encounterand the doctrines and practices of the church. ${ }^{13}$ The Spirit's internal witness validates Christian teaching and learning in conformity with the criteria of "the Word of God revealed in Christ and through the Scriptures."14

Johns insists that the pedagogy of the Holy Spirit "mandates methods of instruction appropriate for life in the Kingdom of God," which bear "the markings of the Spirit's presence" and is to be "considered a means of communion with God," carried out primarily by means of "participation in corporate life with the Spirit." ${ }^{15}$ A critical element is an environment of spiritual formation, including openness to the Spirit's gifting and charismatic activities. Johns neatly sums up:

The pedagogy of the Holy Spirit calls forth an approach to Christian education that takes seriously the historical doctrines, practices, and experiences of the church. It requires fresh awareness that the church is to be the temple of the Holy Spirit, that the Spirit is to be known in powerful manifestations, that the church has been called to be God's contrast society on earth, and that membership in the family of God requires discipline and transforming encounters with God. The pedagogy of the Holy

\footnotetext{
10 Jackie David Johns, The Pedagogy of the Holy Spirit According to Early Christian Tradition (Cleveland, TN: CPM Press, 2012), 147-153.

11 Johns, The Pedagogy of the Holy Spirit, 150. Both Jackie and Cheryl Bridges Johns (see below) understand spiritual formation and transformation against the backdrop of a Wesleyan-Pentecostal theology of regenerating and sanctifying grace.

12 Johns, 150.

13 Johns, $15^{-}-5^{2}$.

14 Johns, 152.

15 Johns, 152 .
} 
Spirit is a pedagogy which actualizes redemption unto God through the Spirit's work in and through individuals. ${ }^{16}$

Possible implications of Jackie Johns' work for the process of theological interfaith education in a Pentecostal institutional setting include the following: (1) An understanding of the Holy Spirit as Teacher affirms the value and guides the implementation of the educational process. (2) Connection with the church's ancient and ongoing legacy establishes helpful parameters. Thus, we can also look at the Church's interreligious history in terms of engagement with other communities at the time of Jesus and beyond. (3) Openness to innovative ideas and instruction enables constructive instruction relevant to the various demands of the present. (4) An acceptance that powerful manifestations of the Spirit can occur in educational settings adds a significant vivifying dynamic. (5) Considering the church as an alternative society, as Johns does, creates opportunities for innovative social applications with appropriate contextual sensitivity. (6) Approaching theological education as a discipline involving moral and spiritual transformation adds a critical ethical dimension to interfaith education and training. (7) Seeing theological education as participating in God's soteriological purpose and having pneumatological power provides an exciting avenue into an explicitly Pentecostal affirmation of interfaith education and vocation. (8) Pedagogy as redemptive actualization reinforces and sustains an approach to interfaith theological education that integrates knowing, being, and doing as individuals in a called and gifted community of Christians coexisting in a world of multiple faiths.

In Pentecostal Formation: A Pedagogy Among the Oppressed, Cheryl Bridges Johns argues that Pentecostals employ a powerful catechetical formation that moves beyond the rationalism of typical praxis epistemology. ${ }^{17}$ She focuses on the impact of Pentecostalism on marginalized peoples. Given that in today's religiously complex world marginalization is too often descriptive not only of negative economic, gender, or racial and social stratification, but also applies to religious, particularly interreligious, social perceptions and identities, her work has significant applications for my theme.

Cheryl Johns describes Pentecostalism as a movement of conscientization, of becoming knowledgeable, aware - that is, conscious - of actual reality. This awareness includes one's own identity, environment, or surroundings, and can lead to transformative social action aimed at "justice, peace, dialogue

\footnotetext{
16 Johns, 153 .

17 Cheryl Bridges Johns, Pentecostal Formation: A Pedagogy among the Oppressed, Journal of Pentecostal Theology Supplement Series 2 (Sheffield, UK: Sheffield Academic Press, 1993, 1998).
} 
and authentic self-giving love."18 For Pentecostals, Spirit baptism is "the unveiling of a new reality and the realization of an altered consciousness," a mode of awareness that can be described as a "critical consciousness."19 Pentecostal conscientization therefore issues forth in a Spirit-driven impetus toward transformational social action. ${ }^{20}$ A Pentecostal environment conducive to conscientization includes the spiritual-affective and oral dimensions of human interaction, essentially "empowering people to know themselves in a transformative way."21 The context of Pentecostal conscientization is worship, learning, and service to community, and involves universal participation in a "paradigm of catechesis." ${ }^{2}$

Cheryl Johns defines Pentecostal catechesis in a manner consistent with Pentecostalism's understandings of reality, knowledge, and the meaning of Christian faith and how it is developed. She asserts that Pentecostal catechesis is "the means by which the Pentecostal community becomes aware of God's revelation and responds to this revelation in faithful obedience."23 Consequently, its goal is to promote lived Christian faith in the community of faith and in the world at large, and the content of such catechesis is a dialectical relationship with experience evaluated by the norms of Scripture. Students are fully active participants working with the teacher under God's initiative; teachers are facilitators of God's actions and presence in the teaching-learning community in the context of worship; while the faith community itself serves a role in the learning setting through liturgical practices of water baptism, communion, testimony, healing rituals, Spirit baptism, and songs and dances. ${ }^{24}$ The not inconsequential effects of this catechetical paradigm are clear: "The church retains it prophetic identity, maintaining an ongoing dialectic between itself and the socio-political environment in which it exists. As a unique, confessional community of faith, the environment may be characterized as exhibiting the characteristics of mutuality, dialogue, love, openness and critical reflection." 25

Clearly, Cheryl Johns' catechetical paradigm has manifold applications for both churches and schools. My focus is more specific: What are some possible implications of her work for the process of theological interfaith education in

\begin{tabular}{ll}
\hline 18 & C. Johns, 62, 81. \\
19 & C. Johns, 95. \\
20 & C. Johns, 96. \\
21 & C. Johns, 109. \\
22 & C. Johns, 110. \\
23 & C. Johns, 121. \\
24 & C. Johns, $125^{-29 .}$ \\
25 & C. Johns, 130.
\end{tabular}


a Pentecostal institutional setting? The affective and transformational dynamic, along with the pneumatological and communal context for pedagogical formation noted in Jackie Johns' work are found in Cheryl Johns' work as well. She focuses more on Pentecostalism's impact on and responsibility for marginalized, oppressed peoples. Marginalization and oppression do not result only from economic, gender, racial, or social stratification, but also from diverse religious identities. ${ }^{26}$ Theological educators thus need to recognize their responsibility to facilitate reconciliation between religious communities.

Additional dynamics arising out of reflection on Cheryl Johns' work include the following

First, an accent on the prophetic nature of Christian education inspires and effectively enables theological educators to embrace the explosive and provocative nature of interfaith issues. Second, an ongoing dialectic between religious educational institutions and their sociopolitical environment encourages the addressing of complex social issues, such as diversity of religions, from a standpoint of the strength that flows out of authentic religious faith. Third, a confessional community is free to identify unapologetically with and express loyalty toward its own heritage of doctrines and practices without demonizing religious others-thus maintaining a nonporous definition of the religious self via the religious other. Fourth, a confessional community supplies essential attitudinal and praxis-oriented resources for interfaith instruction and interaction through such characteristics as mutuality, dialogue, love, openness, and critical reflection. Finally, the overall centrifugal force of pneumatological, transformational energy propels theological educators, along with their students, beyond the classroom into interfaith engagement in theologically-informed activism with an alert sensitivity to social conditions.

Having articulated a Pentecostal philosophy of education suitable for interfaith instruction and engagement, I suggest that the inherent ethos of Pentecostal theological education is a fertile field for addressing interfaith issues. However, much import resides in the relatively new and still developing understanding of the theology of religions among Pentecostals.

26 Reinhold Niebuhr observes that "religious diversity remains potentially the most basic source of conflict." The Children of Light and The Children of Darkness: A Vindication of Democracy and A Critique of Its Traditional Defense (New York: Charles Scribner's Sons, 1944, 1960), 125 . 


\section{Theological Foundation: The Present State of Christian Theology of Religions from Evangelical/Pentecostal Perspectives}

Neither Evangelicalism nor Pentecostalism are monolithic entities; both are characterized by a great deal of diversity. Further, while not completely synonymous, Evangelicalism and Pentecostalism are nearly interchangeable terms in many people's minds and they do have a great deal of overlap and are often closely aligned. ${ }^{27}$ Together, Evangelicals and Pentecostals represent a significant block of more or less conservative Christians, offsetting rigid, censorious fundamentalist movements with an alternative to liberal, modernist movements. From this perspective, Evangelicals are a moderating entity, but they are nevertheless predominately conservatively-oriented Christians, often perceived as politically right-wing. ${ }^{28}$

However, the so-called "New Evangelicals" have returned to earlier "reformist imperatives," and although not without resistance, are becoming more engaged in a wider range of social issues than traditional Evangelicals, including concerns about cultural Islamophobia. ${ }^{29}$ Though there is no clear consensus, some Evangelicals are discovering value in cooperative partnerships across religiously plural lines to battle encroaching secularism and global suffering. ${ }^{30}$ Shared concerns for religious liberty at times transcend religious differences. For instance, the National Association of Evangelicals (NAE) and the Ethics and Religious Liberty Commission petitioned a court on behalf of a

27 Evangelicalism is a loosely defined movement usually signifying distinctive commitments to a quadrilateral of conversionism, biblicism, crucicentrism, and activism. See David Bebbington, Evangelicalism in Modern Britain: A History from the 1730 s to the $1980 \mathrm{~s}$ (New York: Routledge, 2002). Pentecostals mostly agree, but have their own distinct emphases, particularly in pneumatology, charismology, and eschatology. See Vinson Synan, "Evangelicalism," in Burgess and Van Der Maas, eds., The New International Dictionary of Pentecostal Charismatic Movements, 613-16. Conversely, Pentecostalism has been described as "a more radical wing" of Evangelicalism - albeit at odds with fundamentalism. Frances Fitzgerald, The Evangelicals: The Struggle to Reshape America (New York: Simon \& Schuster, 2017), 71, 164.

28 Vinson Synan, "Fundamentalism," in Burgess and Van Der Maas, eds., The New International Dictionary of Pentecostal Charismatic Movements, 655-58. Cf. Fitzgerald, The Evangelicals, 5-6, 278, 559 .

29 Fitzgerald, The Evangelicals, 616; cf. 561, 564, 599. A recent issue of Evangelical Interfaith Dialogue was dedicated to discussing Islamophobia, including my article, "A Brief Response to Islamophobia by a Pentecostal Observer," Evangelical Interfaith Dialogue (Fall 2016): 40-41.

Fitzgerald, The Evangelicals, 423, 425, 550, 562 . 
Muslim group denied the right to build a mosque. ${ }^{31}$ These developments are encouraging for those convinced of the positive significance of interreligious education, dialogue, and cooperation.

Evangelicals/Pentecostals have a checkered history of relations with other religions. What is more, attitudes toward religious others varies greatly depending on a range of factors and a priori views flowing out of various subgroup dynamics. Early and substantial immigration to the United States, as well as certain eschatological schemas, tended to make for more than usual openness toward Jews (and the State of Israel), but extremist elements, often with fundamentalist features, resisted even this small move toward diversity. ${ }^{32}$ To be fair, Evangelicals/Pentecostals rightly object to the unequal status and unjust treatment of women in Hinduism, Buddhism, and Islam, especially in their fundamentalist versions, and to human rights and religious freedom abuses. ${ }^{33}$ Certainly some American Evangelicals fear "fringe" groups like the Hare Krishna and Scientologists, and consider world religions such as Hinduism and Buddhism, as religious rivals. ${ }^{34}$ Overall, Islam has been the major concern for many contemporary Evangelicals and continues to be so, though some exhibit slight signs of increasing openness toward Muslims.

Admittedly, Christian-Muslim history in general has been heavily laden with mutual distrust, fear, and violence. ${ }^{35}$ In the aftermath of $9 / 11$, a volatile mix of theological ideas and geopolitical commitments, especially Christian Zionist hostility toward Islam, contributed to American Evangelicals' rampant demonization of Muslims, including American Muslims. While some distinguish between radical Islamist groups, associated with global terrorism, and mainstream Islam as a peaceful religion, many do not, and many of those who do make this distinction often do not take adequate time to articulate the reality of moderate Muslims. A tragic consequence has been an almost

$31 \quad$ Fitzgerald, 634.

32 Fitzgerald, 58, 80, 112, 144-45, 341. At least in part, ambivalent attitudes toward Jews among mostly conservative Evangelicals are traceable to alignment of Reformed Judaism with liberal politics, 462,502 .

To be fair, there is internal debate among various Evangelical and Pentecostal groups regarding the role of women in the home, in church, and in society. However, debates over appropriate roles for women do not imply acceptance of inhumane or unjust treatment of women. See the reference to Grady, note below.

34 Lee J. Grady, Twenty-Five Tough Questions about Women and the Church: Answers from God's Word that will Set Women Free (Lake Mary, FL: Charisma House, 2003), 43-44, 106; Fitzgerald, The Evangelicals, 222, 461.

Justo L. Gonzalez, A History of Christian Thought in One Volume (Nashville, TN: Abingdon, 2014), 157, 180, 328. There have been positive cultural and philosophical exchanges as well, $194-96$. 
universally negative view of Muslims. ${ }^{36}$ American Evangelicals' default negative perspective of Islam often results in automatic and implacable hostility toward Muslims, including American Muslims. ${ }^{37}$

Some Evangelical leaders, pastors, and educators, however, are working to inform their constituencies about disagreements within Islam itself regarding the role of the religion in peace and violence. ${ }^{38}$ The spectrum of Evangelical sentiment toward Muslims is illustrated in the following: Franklin Graham, controversial son of popular evangelist Billy Graham, warns against Islam in the strongest possible terms, suggesting the religion itself is as a whole "wicked," while Richard Cizik, former NAE leader and current New Evangelical activist, worries that some are simply projecting previous fears, and inflammatory rhetoric about the Soviet Union and the "Evil Empire" onto Islam. ${ }^{39}$ Perhaps most surprising is that in such a combative climate, Evangelical/Pentecostal theologies of religions have begun to develop and, to an extent, thrive.

Contemporary Evangelical/Pentecostal theologies of religions owe much to Norman Anderson and Stephen Neill. ${ }^{40}$ Anderson rejects relativistic pluralism

36 Fitzgerald, The Evangelicals, $475^{-80}$. It is interesting that conservative Evangelicals, Orthodox Jews, and Muslims are political partners in opposing same-sex marriage, 490. Inconsistencies surface: one of the charges some Evangelicals repeatedly leveled against President Barack Obama was that he had been raised Muslim, 578, 593. During the 2016 presidential campaign Donald Trump played on Evangelicals' fear of Islam by suggesting, and later attempting, a moratorium on Muslims entering the United States. However, though approved at the populist level, leading Evangelical thinkers (e.g., Russell Moore) recognized this as blatant violation of religious liberty, 228 .

37 Doubtless racism plays a significant role in Islamophobia in the United States and elsewhere. See Catherine Orsborn, "Standing Shoulder to Shoulder Against Anti-Muslim Bigotry," Evangelical Interfaith Observer (Fall 2016): 26-27; Richard McCallum, "Islamophobia: A View from the UK," Evangelical Interfaith Observer (Fall 2016): $3^{2-33}$. However, it is a distracting mistake to equate racism, sexism, and religious prejudice-even though they exist with a great deal of categorical overlap. Tony Richie, "A Pentecostal Take on Islamophobia," Evangelical Interfaith Dialogue (Fall 2016): 40-41. Such related dynamics ought to be considered without collapsing the distinctive nature of religious prejudice itself. Only then can the religious component be adequately addressed.

38 E.g., Jim Denison, "immediately after a jihadist terrorist attack in Manchester, England on May 23, 2017, wrote "Islam: Religion of Violence or Peace?” Denison Forum on Truth in Culture, accessed October 10, 2019, http://assets.denisonforum.org/pdf/Islam\%20a\%20 religion\%20of\%2oviolence\%20or\%2opeace_pdf. Denison acknowledges the complexity of the Koran and of Islamic thought, but distinguishes between "Medina" Muslims, a small minority of violent radicals, and "Mecca" Muslims, mainstream, moderate Muslims dedicated to the peaceful practice of their faith. See also Denison's earlier work, Radical Islam: What You Need to Know, Unlocking the Truth Series (Atlanta, GA: Elevation Press, 2011).

39 Fitzgerald, The Evangelicals, 475.

40 In Encountering Religious Pluralism: The Challenge to Christian Faith \& Mission (Downers Grove, IL: InterVarsity Press, 2001), Harold Netland offers a helpful survey of Evangelical theology of religions. The diverse influence of figures such as John Wesley and C. S. Lewis, 
and religious syncretism, insisting on a Christocentric soteriology and evangelistic missiology. He acknowledges, however, that God's Spirit works in some sense in and among those of non-Christian religions, and refuses to assume that all non-Christian devotees are automatically and inevitably damned by definition. ${ }^{41}$ Anderson's theology of religions leads him into cautious acceptance of interreligious dialogue and cooperation conducted in mutual respect as a component of ecclesial mission. ${ }^{42}$

Neill is an uncompromising Evangelical but tends to be complex and paradoxical. He holds together strong commitments to ecumenism and evangelism, high Christology, and real respect for religious others. ${ }^{43}$ Neill avoids Christian compromise or self-assertion, on the one hand, while celebrating the discovery of Christ among the religions on the other hand. ${ }^{44}$ Further, no mere theoretician, Neill models dialogue in direct interaction with Jews, Muslims, Hindus, Buddhists, and others. ${ }^{45}$ Both Anderson and Neill are "committed to maintaining the tension" between "a high Christology and distinctive Christian soteriology with hopeful openness toward those of other faiths." Neill particularly stresses the mutual benefit and appreciation that comes through dialogical engagement. ${ }^{46}$ The examples of Anderson and Neill demonstrate that staunch Evangelical commitment is not incompatible with interfaith theological involvement.

Baptist Charismatic theologian Clark Pinnock has had pivotal influence on contemporary Pentecostal theologies of religions. ${ }^{47}$ Admittedly, Pinnock's provocative work has not been without controversy. ${ }^{48}$ While maintaining typical Evangelical commitments to high Christology, soteriology, and missiology (viz., evangelism), Pinnock uncharacteristically turns to pneumatology as the rationale for his treatment of the theology of religions. ${ }^{49}$ For Pinnock, Jesus

as well as Karl Barth, are felt too. Cf. Tony Richie, Toward a Pentecostal Theology of Religions: Encountering Cornelius Today (Cleveland, TN: CPT Press, 2013), 55-56. Norman Anderson, Christianity and World Religions: The Challenge of Pluralism rev. ed.(Downers Grove, IL: InterVarsity Press, 1970, 1984), 16-20, 30-34, 45-55. Anderson, Christianity and World Religions, 139-40, 184-91.

43 Netland, Encountering Religious Pluralism, 47.

44 Stephen Neill, Christianity and Other Faiths: Christian Dialogue with Other Religions (New York: Oxford University Press, 1961, 1970), 4-5, 18-19, 207.

45 Neill, 20, 40, 70, 99, 125, etc.

46 Richie, Toward a Pentecostal Theology of Religions, 54.

47 Clark H. Pinnock, popular among Pentecostals, has a major treatment of theology of religions in Chapter 6 of Flame of Love: A Theology of the Holy Spirit (Downers Grove, IL: InterVarsity Press, 1994). See also A Wideness in God's Mercy: The Finality of Jesus Christ in a World of Religions (Grand Rapids, MI: Zondervan, 1992).

48 Netland, Encountering Religious Pluralism, 309. Netland commends Pinnock's work but suggests it goes "well beyond" most Evangelicals' comfort zones, 310. 
Christ represents the concrete historical and efficacious manifestation of God's redemptive love, while the Holy Spirit transcends time and space in extending salvific benefits beyond ecclesial borders. In other words, the Spirit of Christ is at work in the wider world, including the religious world, carrying out, at least potentially, God's redemptive purposes. Significantly, Pinnock does not describe non-Christian religions as vehicles of salvation, but neither is the Spirit restricted to the Christian church. Pinnock advocates for God's global reach and compassionate concern for the salvation of all peoples, while affirming God's gracious revelation in Jesus Christ as definitive and final. ${ }^{50}$

Pentecostalism's early precedents regarding a Christian theology of religions include Charles Parham and, most notably, J. H. King. Parham, a prominent founding leader in the early stages of the modern Pentecostal revival, offered scattered but suggestive anecdotal and homiletic reflections on non-Christian religions. ${ }^{51}$ In essence he advocated "eschatological inclusivism" - a combined commitment to Christological uniqueness and soteriological necessity with measured openness to the potential redemption of non-Christian religious adherents, which is to be ultimately completed in the eschaton. ${ }^{52}$ Parham did not engage in formal interreligious dialogue, but his personal relationships included interaction with friends of other faiths, notably a Jewish rabbi. ${ }^{53}$

King was a long-term, highly respected denominational administrator in the International Pentecostal Holiness Church. ${ }^{54} \mathrm{He}$ was not a systematic theologian and tended to address topics as they came up in his duties as an administrator and preacher. Nevertheless, King had some formal theological training and his writings reveal careful reflection and consistent emphases regarding what we can anachronistically call a Christian theology of religions. Furthermore, his international travels brought him into direct and repeated contact with other religions and their adherents.

King displays a stable orientation to Christology, 55 emphasizing both the historical, temporal Christ of the incarnation and the universal, eternal Christ,

$50 \quad$ Pinnock, Flame of Love, 179; Wideness in God's Mercy, 13.

51 See Charles F. Parham, The Sermons of Charles F. Parham (New York: Garland, 1985), a collection of earlier and separate works by Parham published under the titles $A$ Voice Crying in the Wilderness (1902) and The Everlasting Gospel (1919).

$5^{2}$ Tony Richie, "Eschatological Inclusivism: Early Pentecostal Theology of Religions in Charles Fox Parham," Journal of the European Pentecostal Theological Association 27, no. 2 (2007): 138-52.

53 Parham, A Voice Crying in the Wilderness, in The Sermons of Charles F. Parham, 103-104.

54 See the denominational website of the IPHC, accessed October 10, 2019, http://iphc.org/.

55 Tony Richie, "Azusa-era Optimism: Bishop J. H. King's Pentecostal Theology of Religions as a Possible Paradigm for Today," in Veli-Matti Kärkkäinen, ed., The Spirit in the World: Emerging Pentecostal Theologies in Global Contexts, preface by Jürgen Moltmann (Grand Rapids, MI: Eerdmans, 2009), 227-44. 
thus rooting redemption in the historic Christ event, but without limiting Christ or redemption to time or place. King's theology of religions relies on a doctrine of the general atonement, the reality and efficacy of general revelation, and the Holy Spirit's progressive work in religious experience. ${ }^{56} \mathrm{He}$ maintains the uniqueness and superiority of Christianity, while distinguishing institutional Christianity from "the religion of Christ," ${ }^{57}$ which means the preincarnational, hidden work of God in all of humanity, which is nevertheless dependent upon Christ and the universal agency of his Spirit. ${ }^{58}$ In this vein, King insists that the Book of Jonah provides biblical precedent for ongoing openness to God's redemptive purpose beyond the Judeo-Christian religious tradition. ${ }^{59}$ King's concept of the religion of Christ potentially transcends dogmatic, rigid boundaries of religious institutions to open up remarkable avenues for multifaith discussions.

Veli-Matti Kärkkäinen, Amos Yong, and Tony Richie are the primary contributors to the contemporary Pentecostal theology of religions and accompanying interreligious dialogue and cooperation. ${ }^{60}$ Kärkkäinen is a prolific Pentecostal theologian with two books focusing on the topic of theology of religions. ${ }^{61} \mathrm{He}$ identifies the doctrine of the Trinity as the chief distinguishing characteristic of Christian theology, but gives it specific application for a Christian theology of religions. Kärkkäinen's theology of religions represents an ecumenical approach from a Pentecostal perspective. He is sharply critical of the ideology of religious pluralism, particularly objecting to any diminishment of

56 J. H. King, From Passover to Pentecost (1911) (Franklin Springs, GA: Advocate Press, 1976, fourth ed.), 101; Christ-God's Love Gift: Selected Writings of J. H. King, vol. 1 (Franklin Springs, GA: Advocate Press, 1969), 136.

57 J. H. King, “Today," The Pentecostal Holiness Advocate 9, no. 31 (December 1925): 1, 8.

$5^{8}$ I make a comparison between King's "religion of Christ" and Tillich's "Religion of the Concrete Spirit" in "What Have Pentecostals to Do with the 'Religion of the Concrete Spirit'? Paul Tillich's Theology of Religions in Twenty-First Century Global Renewal Context," in Nimi Wariboko and Amos Yong, eds., Paul Tillich and Pentecostal Theology: Spiritual Presence and Spiritual Power (Bloomington, IN: Indiana University Press, 2015), 150.

59 J. H. King, “Jonah's Gourd," The Pentecostal Holiness Advocate 2o/29 (November 1936): 1-2.

6o While not concentrating on theology of religions per se, Frank D. Macchia addresses it in a significant fashion, Frank D. Macchia, Baptized in the Spirit: A Global Pentecostal Theology (Grand Rapids, MI: Zondervan, 2006), 178-90, and Steven M. Studebaker, From Pentecost to the Triune God: A Pentecostal Trinitarian Theology (Grand Rapids, MI: Eerdmans, 2012), 208-39.

61 Veli-Matti Kärkkäinen, An Introduction to the Theology of Religions: Biblical, Historical, and Contemporary Perspectives (Downers Grove, IL: InterVarsity Press, 2003) and The Trinity and Religious Pluralism: The Doctrine of the Trinity in Christian Theology of Religions (Burlington, VT: Ashgate, 2004). 
the doctrines of the Trinity and of a high Christology, and also to derivative attempts to bypass the question of absolute truth. ${ }^{62}$

For Kärkkäinen, communion, unity, and difference come together in the divine being. The Trinity extends communion through self-revelation to the other, to those who are different, providing the paradigm for human relationships, including for interreligious engagement, with respect for tolerance, and recognition of the blessings and challenges of real differences. ${ }^{63}$ As a Pentecostal and ecumenical theologian, Kärkkäinen offers an inviting and positive approach to the Christian theology of religions.

Amos Yong, a Malaysian immigrant to the United States from a Buddhist family prior to their Christian conversion, has several major works on the theology of religions. ${ }^{64}$ His is a distinctively Pentecostal theology in which he proposes that the Pentecostal experience produces a unique "pneumatological imagination," or a way of theologizing informed by an experience of and orientation toward the Holy Spirit, which in turn suggests possibilities of the Spirit's presence and influence in the world and in the world's religions. ${ }^{65}$ Accordingly, Yong develops a "foundational pneumatology" that supports a pneumatological interpretation of other religions and a "general understanding of divine presence and activity." 66 For Yong, the presence and activity of the Holy Spirit throughout the world, even beyond the Church, has implications for alethiology and soteriology. Whatever truth or grace is present in the religions, or among their adherents, can be attributed to the Spirit of Christ, even apart from any explicit epistemological awareness.

Yong highlights the need for discernment in a world of diverse spirits. Christian discernment in the Pentecostal-Charismatic tradition includes both divine gifting and human discretion. Criteria for discerning the Holy Spirit from other spirits include the fruit of the Spirit, ethical conduct, and signs of the

62 Kärkkäinen, An Introduction to the Theology of Religions, 354; cf. 113-15. Kärkkäinen stands squarely in the biblical, historic theological tradition, but simultaneously shows keen awareness of the Christological interpretations of other religions, entering into respectful dialogue accordingly. Cf. Christ and Reconciliation: A Constructive Christian Theology for the Pluralistic World (Grand Rapids, MI: Eerdmans, 2013), 210, 236, 381.

63 Kärkkäinen, The Trinity and Religious Pluralism, 180-82.

64 E.g., Amos Yong, Discerning the Spirit(s): A Pentecostal-Charismatic Contribution to Christian Theology of Religions (Sheffield, UK: Sheffield Academic Press, 200o); Beyond the Impasse: Toward a Pneumatological Theology of Religions (Grand Rapids, MI: Baker, 2003); Hospitality and the Other: Pentecost, Christian Practices, and the Neighbor (Maryknoll, NY: Orbis, 2008); and Pneumatology and the Christian-Buddhist Dialogue: Does the Spirit Blow through the Middle Way? (Leiden and Boston: Brill, 2012).

65 Yong, Discerning the Spirit(s), 29-31, Chapter 4.

66 Yong, 98, 122-32. 
coming Kingdom. ${ }^{67}$ Within this theological framework, "the pneumatological imagination derived from the outpouring of the Spirit" enables a relatively impartial, sympathetic, yet critical engagement with the religions. ${ }^{68}$ Yong's doctrine of discernment sounds an emphatic Pentecostal note and helps guard its uniquely Christian character. Endeavoring to properly relate Christology and pneumatology, he describes the Holy Spirit as "both universal and particular, both the Spirit of God and the Spirit of Jesus the Christ." ${ }^{69}$ Although Yong obviously stresses the Spirit's presence in the world and its religions, he does not sacrifice the uniqueness or necessity of Jesus Christ in the process.

Like Kärkkäinen, Yong's theology of religions leads naturally to interreligious dialogue in the context of Christian mission. Dialogue serves the righteousness, peace, and truth inherent in God's Kingdom. Meaningful dialogue is both a "journey of critical self-discovery" and a "faithful Christian discernment of the other."70 He nonetheless insists that a Pentecostal theology of religions should "invigorate the proclamation of the Christian gospel even as it recognizes the eschatological horizon of the Holy Spirit's presence and activity."71 Overall, Yong's theology of religions is somewhat paradoxical in nature: it emphasizes pneumatology together with Christology, and interreligious dialogue together with Christian evangelism.

My own work is mostly in continuity with Kärkkäinen and Yong, with more of a Wesleyan-Pentecostal focus and an emphasis on testimony as dialogue. ${ }^{72}$ Affirming robust Trinitarian and pneumatological emphases, I stress the importance of continuity with early strands of Pentecostal theologies of religions

67 Yong, 243-55.

68 Amos Yong, The Spirit Poured Out on All Flesh: Pentecostalism and the Possibility of Global Theology (Grand Rapids, MI: Baker, 2005), 254.

69 Yong, Beyond the Impasse, 21.

70 Yong, Discerning the Spirit(s), 143. In my experience, Pentecostal theologies of religions and interreligious dialogue exhibit bilateral movement. On the one hand, an inclusive theology of religions inspires and informs dialogue and mutual enrichment occurs. On the other hand, exclusive assumptions tend to dismiss dialogue as at best irrelevant or at worst a compromise of identity and mission. Missiologically, and therefore pedagogically, the focus defaults to apologetics and evangelism and a robust theology of religions is minimized or eliminated.

$71 \quad$ Yong, Discerning the Spirit(s), 313.

72 See Tony Richie, Speaking by the Spirit: A Pentecostal Model for Interreligious Dialogue, Asbury Seminary Series in World Christian Revitalization Movements in Pentecostal/ Charismatic Studies 6 (Lexington, KY: Emeth Press, 2011), and Toward a Pentecostal Theology of Religions: Encountering Cornelius Today (Cleveland, TN: CPT Press, 2013). 
(however informal or undeveloped), and of creativity in utilizing the Pentecostal practice of testimony as a model for interreligious dialogue. Pentecostals may thus utilize a paradigm for contemporary conversations before God with others. My approach is sectarian and traditional in the sense that it is quite self-consciously Pentecostal, but it is also ecumenical and contemporary in the sense that it incorporates a wide range of insights and practices up to and including the present state of Christian theologies of religions and the practice of multifaith dialogue.

I propose a theology for interreligious dialogue undergirded by a theology of religions. I argue that the Wesleyan-Pentecostal heritage of pneumatological/ prevenient grace is rich with resources for today's theology of religions, while proposing a radical revamping of the Christian mission to integrate evangelism with dialogue. ${ }^{73}$ I draw on Anglo-Catholic resources to help in understanding the history of religions even as I insist on a staunch Pentecostal hermeneutic for understanding the nature of religious truth. ${ }^{74}$ Further, I find that a conversation with mainstream Protestant theology on pneumatology can be mutually informative because of the Pentecostal affirmation of a public/political theology for interfaith appreciation and respect in the civil realm. ${ }^{75}$ My essential assumption is that Pentecostalism contains a legitimate ecumenical impulse that further translates into authentic multifaith involvement. ${ }^{76} \mathrm{My}$ enduring goal is for a Pentecostal theology of religions that is open to others without compromising its own identity. ${ }^{77}$

Roots in Evangelicalism and early Pentecostalism along with contemporary developments form the content and shape of a Christian theology of religions

73 Tony Richie, "Mr. Wesley and Mohammed: A Contemporary Inquiry Concerning Islam," Asbury Theological Journal 58, no. 2 (Fall 2003): 79-99; "Revamping Pentecostal Evangelism: Appropriating Walter J. Hollenweger's Radical Proposal," International Review of Mission, 96 (July/October 2007): 343-54.

74 Tony Richie, "Hints from Heaven: Can C. S. Lewis Help Evangelicals Hear God in Other Religions?" Evangelical Review of Theology 32, no. 1 (January 2008): 38-55; "Approaching Religious Truth in a Pluralistic World: A Pentecostal-Charismatic Contribution," Journal of Ecumenical Studies 43, no. 3 (Summer 2008): 351-69.

75 Tony Richie, "A Politics of Pluralism in American Democracy: Reinhold Niebuhr's Christian Realism as a National Resource in a Post-9/11 World," Journal of Ecumenical Studies 45, no. 3 (Summer 2010): 471-92.

76 I describe the bases and implications of this assumption in "Correlating Intra-Christian Relations and Interreligious Realities," in Peter Hocken, Tony Richie, and Christopher A. Stephenson, eds., Christian Unity and Pentecostal Faith (Leiden, Netherlands: Brill, forthcoming), Chapter 15 .

77 Tony Richie, "Neither Naïve nor Narrow: A Balanced Approach to Pentecostal Theology of Religions," Harold D. Hunter, ed., Cyberjournal for Pentecostal-Charismatic Research 15 (2006), last accessed 10 October, 2019, http://www.pctii.org/cyberj/cyberj15/richie.html. 
from a Pentecostal perspective. This form and content is staunchly Trinitarian, faithfully Christological, robustly pneumatological, and intentionally integrates the ecclesiological, missiological, and dialogical. It readily supplies Evangelical/Pentecostal educators with sufficient material for the work of theological education in the discipline.

\section{Application: Interfaith Instruction and Encounter in the Classroom and Beyond}

Sebastian Kim and Kirsteen Kim assert that Christianity should be studied as a world religion. If they are correct, and as they acknowledge, this would change the way Christianity is taught and studied. ${ }^{78}$ To be more explicit:

The challenge we wish to bring ... is not merely that Christianity is a nonWestern religion because historically its origins are in Asia; nor just that non-Western Christianities should be taken more seriously by theologians and scholars of Christianity because Christianity's numerical strength now lies in the Global South. What we argue is that all aspects of Christian studies, including church history, theology, interreligious and societal relations, must be reshaped and revised in light of the nature of Christianity as a world religion. ${ }^{79}$

The authors suggest that studying Christianity in the context of other religions would clarify both its own distinctiveness and its commonality with others, giving Christians an outsider's view of their faith, and overcoming the unfortunate and commonplace historical tendency to neglect or suppress interreligious studies. ${ }^{80}$ Nevertheless, they acknowledge that studying Christianity against the backdrop of religious plurality is a complex business, requiring careful balance and contextual abilities. ${ }^{81}$ The point I wish to emphasize is that effectively studying and teaching Christianity in today's religiously plural global setting positively requires interreligious studies also.

Two considerations are especially noteworthy for Pentecostal theological education. First, since Pentecostalism's rapid and widespread growth and

78 Sebastian Kim and Kirsteen Kim, Christianity as a World Religion: An Introduction (London/New York: Bloomsbury Academic, 2008, second ed., 2016), 282.

79 Kim and Kim, 286.

8o Kim and Kim, 282-83.

81 Kim and Kim, $283-84$. 
ardent evangelistic impulse brings it into frequent, and sometimes volatile, encounter with other religions, the need for interfaith theological education is particularly pressing. ${ }^{22}$ Second, since Pentecostal perceptions of salvation and spirituality are holistic, encompassing all of life, then life encounters with contemporary religious diversity should be acknowledged and interpreted through the insights of this distinctive worldview. ${ }^{83}$ In short, both theological and practical conditions make the development and teaching of a Pentecostal theology of religions expedient. To reiterate, the survey of the discipline above indicates, to my mind, the direction and tone that might best be adopted in such a theology.

It is true that Pentecostals are not generally known for ecumenical, much less multifaith, sensitivity or involvement. There have been, however, significant exceptions to generally closed attitudes through "the ecumenism of the Spirit." 84 Pentecostal theology is traditionally conservative, yet emphasis on "the freedom of the Spirit" distances Pentecostals from rigid fundamentalism, potentially creating a generous space for greater openness to others. ${ }^{85}$ For myself, ecumenism and interfaith work have been concomitant and symbiotic. In dialogues with adherents of non-Christian faiths I have realized that nonChristians often view Christians in a monolithic manner that is not representative of actual reality. Accordingly, I have come to a greater appreciation of Christian diversity, and I am able to recognize more diversity among conversation partners from other faiths than I once did.

Consequently, I tend to emphasize insights from my own tradition with appreciation and respect for other Christian traditions, as well as for other religions. I have been aided significantly in increasing attitudinal openness by the remarkably permeable nature of the Pentecostal faith tradition, made possible,

82 Kim, Kim and Kim, 19; cf. 282, 284.

83 Allen Anderson, "Pentecostal and Charismatic Theology," in David F. Ford with Rachel Muers, eds., The Modern Theologians: An Introduction to Christian Theology since 1918 (Malden, MA: Blackwell Publishing, 2005), 6o3.

84 Carmelo Alvarez, "The Ecumenism of the Spirit: Emerging Contemporary Contexts of Mission in Latin America," in Miguel Alvarez, ed., Reshaping of Mission in Latin America, Regnum Edinburgh Centenary 30 (Eugene, or: Wipf and Stock, 2016), 47-64.

85 Anderson, "Pentecostal and Charismatic Theology," 605. Like Evangelicals, Pentecostals are committed to the Reformation principle of solus Christus, therefore rejecting relativistic pluralism, but Pentecostals are more comfortable with a broader hermeneutic informed by pneumatological explications. David F. Ford, "Evangelical Theology," in Ford with Muers, eds., The Modern Theologians, 614-615. See also Anderson, "Pentecostal and Charismatic Theology," 595-97. 
at least in part, by the robust integration of pneumatology and eschatology ${ }^{86}$ Here I explicitly reference the Holy Spirit's present, anticipatory work of reflecting and ushering in the eschaton, wherein the entire cosmos conforms to God's righteous reign. ${ }^{87}$ This inaugurated eschatology enables an ontological and didactic appropriation of eschatological realities in the present age through the Holy Spirit's presence and power.

Of course, Pentecostal interfaith education and dialogue faces the standard challenges of all Christians. For example, in Asia, Christians are often at pains to distinguish their faith and practice from that of Buddhists or Hindus, ${ }^{88}$ while in parts of Africa and the Middle East Christians are often a minority group struggling for equality in a dominant Islamic culture. ${ }^{89}$ Perhaps most significantly, different understandings of God can complicate even the bestintentioned efforts by the most committed partners. ${ }^{90}$ For instance, Judaism and Christianity disagree on the doctrine of God. Muslims side with the Jews, but charge that the latter have corrupted divine revelation, while Christians stake their identity on the Incarnation, which both Jews and Muslims rejectall of which results in "an intractable theological argument." "1

Additionally, Pentecostals have a confrontational history involving demonization of religious others. ${ }^{92}$ Economic competition, ideological/political quarrels, and xenophobia contribute to encounters of conflict. Complicating matters ever further, Evangelical concern for religious others can come across to their "targets of evangelism" as condescending. ${ }^{93}$ Despite all this, Pentecostal missiology nonetheless encourages benevolent, constructive interreligious encounter (Acts 19:9-10). ${ }^{94}$

86 See Gonzalez, A History of Christian Thought, 348; Steven Jack Land, Pentecostal Spirituality: A Passion for the Kingdom (Sheffield, UK: Sheffield Academic Press, 1993, 2010).

87 Land, Pentecostal Spirituality.

88 Simon Chan, Spiritual Theology: A Systematic Study of the Christian Life (Downers Grove, IL: IVP Academic, 1998), 20, 83, 168, 172, 174.

89 Chan, 28-29, 70.

90 Chan, 44.

91 E. T. Charry, "Judaism," in Dryness and Kärkkäinen, eds., Global Dictionary of Theology, 434, 441.

92 Cephas Omenyo, "Renewal, Christian Mission, and Encounter with the Other," in Amos Yong and Clifton Clarke, eds., Global Renewal, Religious Pluralism, and the Great Commission: Towards a Renewal Theology of Mission and Interreligious Encounter (Lexington, KY: Emeth Press, 2011), 152-53.

93 Charry, "Judaism," 441.

94 Amos Yong and Tony Richie, "Missiology and the Interreligious Encounter," in Allan Anderson, Michael Bergunder, André Droogers, and Cornelius Van Der Laan, eds., Studying Global Pentecostalism: Theories \& Methods (Berkeley, CA: University of California Press, 2010), 245-67. 
Ecumenical-interfaith collaborative partnerships are therefore critical for theological education and ministry praxis today, and I am convinced of the viability of interfaith education for the Evangelical/Pentecostal tradition. I profoundly hope that the Evangelical/Pentecostal tradition may offer constructive and positive insights and experiences for mutual benefit and engaging reciprocity. For these reasons and others, I am committed to the introduction and development of interfaith theological education. I have taught this topic at Lee University in special forums and as a guest lecturer, but my focus is on PTS.

David Sang-Ehil Han, Academic Dean at PTs, has taken steps toward including religious plurality in the educational curriculum. In 2012 Han participated in an Association of Theological Schools forum on "Christian Hospitality in a Multi-Faith Society. ${ }^{\prime 95} \mathrm{He}$ subsequently brought the topic to PTS through a conference on "Christian Hospitality and Neighborliness: A WesleyanPentecostal Ministry Paradigm for the Multi-faith Context," an interdisciplinary, institution-wide event which received broad attention. Han has also supported my efforts to introduce interfaith theological education courses and curriculum, beginning with incorporating interreligious themes into existing course formats. A modest beginning of one credit hour courses featuring texts on the Pentecostal theology of religions quickly advanced further.

In 2013 I co-developed and team-taught with Richard Pace, Endorser and Coordinator of Church of God Chaplains Commission, a three-credit hour $\mathrm{J}$ term on "Theology of Ministry in the Multi-Faith Context." ${ }^{\text {" Th }}$ The course focused on the practical preparation for ministry in multifaith contexts with a Wesleyan-Pentecostal theological foundation. Efforts to integrate this course into the PTS Doctor of Ministry program proved unsuccessful, however; the theological nature of the material was judged too intense for DMin-level work. ${ }^{97}$ Since then either Pace or I have taught the course several times in a directed study format. ${ }^{98}$

95 Sang-Ehil Han, Paul Lewis Metzger, and Terry C. Muck, "Christian Hospitality and Pastoral Practices from an Evangelical Perspective," Theological Education 47, no. 1 (2012):11-31.

96 A "J Term" is a week-long intensive with classroom occurring during either January, June, or July.

97 The DMin or Doctor of Ministry degree is mostly vocational in orientation. It does not require extensive work in theology per se. However, this course was originally designed with an "applied theology" focus.

98 PTs Directed Study is a guided reading course with designated instructor interaction. Admittedly, interfaith theological education may be most effective when it utilizes stratified approaches that allow for practical and theological emphases sensitive to particular course content and projected learning outcomes for a specific student composition. 
In 2015 I designed a full course on "Christian Theology of Religions: A Pentecostal Perspective" for PTS' master's program and have been teaching it regularly ever since as a theology elective. This course is a distinctive offering among Pentecostal educational institutions-it does not focus on comparative religions or evangelistic training; rather, it examines Christian theology of religions per se. Here the ecumenical, interfaith, Evangelical, and Pentecostal intersect. In addition to Scripture and historical theology, the course draws on ecumenical and interfaith resources with an Evangelical and Pentecostal orientation.

I have received generally favorable responses from PTS students on the theology of religions course. Bachelor's program religion students at Lee are, if anything, even more engaged. Younger (under forty) students in particular seem to more readily recognize the need for theological education on interfaith issues. They are also more inclined toward inclusive and open attitudes about religious others. Several older (over fifty) students have also been positive, and some have expressed regret that they did not encounter this subject earlier in their educational journey. I acknowledge that since the theology of religions is not required coursework at PTS, those who are unfavorably inclined may simply avoid it. I speculate that making theology of religions a required course might send a stronger message to students regarding its significance and lead to a concomitant increase in appreciation and participation.

In spite of the innovative and, to an extent, controversial, nature of introducing interfaith education at our institution, I have been affirmed and encouraged by my colleagues among the PT s/Lee faculty and administration and denominational leadership. I sense that most understand the contemporary applicability of this work. I sometimes wonder if the primary urgency of building healthy relationships with religious others of good will is adequately understood as an essential component of ecclesial mission for today's global context. Yet I am encouraged that in a movement that traditionally (rightly) prioritized evangelism, issues of social ethics and ecumenical and interfaith education and dialogue now appear on our institutional and didactic radar much more so than was once the case.

A still developing aspect of PTS theological education involves personal encounters with those of other faiths. For example, I work with Zaynab Ansari, a Muslim scholar from Tayseer Seminary (Knoxville, TN) through firsthand dialogues in PTs and Tayseer classrooms. ${ }^{99}$ After a short presentation we engage in an open conversation. It is necessary to conduct such encounters

99 See the Tayseer Seminary website, accessed October 10, 2019, http://www.tayseerseminary.org/ustadha-zaynab-ansari/. 
circumspectly, however; our constituencies draw sharp lines between dialogue, which is acceptable, and promotion of another religion, which is not. PTS students unanimously favor (by actual class vote) these opportunities for mutual engagement.

Another, more informal, off-campus encounter is a Knoxville initiative known as "A Seat at the Table" (ASATT), ${ }^{100}$ an informal monthly gathering of people of differing faiths for dinner and conversation. I do not require attendance at ASATT for my classes but announce the opportunity and invite interested participants. Nevertheless, several of my students (and some faculty members) have been willing to drive nearly an hour and a half from Cleveland to participate on their own time. They have expressed unanimous appreciation for the opportunity to get to know people of other faiths as human beings. (Partners from other faiths, and those from other Christian traditions, always appear pleased at Evangelical/Pentecostal involvement—if, perhaps, a bit surprised!) I am fully convinced that supplementing our class work with personal encounters makes for a more informative, and transformative, educational experience for PTS students. ${ }^{101}$

Finally, interfaith education also works well in congregational contexts. Through a Jewish friend, David Elcott, Taub Professor of Practice in Public Service and Leadership at New York University, my congregation, New Harvest Church of God (Knoxville, TN), became involved in an extended (2013-2015) study called "The Religion and Civics Project."102 In this program we studied religious freedom, civil discourse, and democracy, especially interfaith intersections. The project utilized a combination of written surveys and congregational discussion forums to devise and field-test a teaching aid, which included a pedagogical video and other materials.

Interestingly, data results tended to debunk presuppositions and break down stereotypes, and thus contributed to constructing an optimistic framework for civil engagement by religious groups across a broad spectrum of ideologies. The process of interfaith education and interaction at the congregational level has had discernible implications for civic policies and practices.

\footnotetext{
100 Lesli Bales-Sherrod, "Strangers of Differing Faiths Take a Seat at the Table and Leave as Friends," Knoxville News Sentinel, July 22, 1916, accessed October 12, 2019, http://archive .knoxnews.com/entertainment/life/strangers-of-differing-faiths-take-a-seat-at-the-tableand-leave-as-friends-3827deco-9e6d-1074-e053--387954982.html.

101 Furthermore, tendencies toward dehumanizing (or demonizing) others are offset by personal encounters with the other as a human being.

102 See "Religion and Civics Program, NYU Wagner, accessed Octoeber 12, 2019, https:.." // wagner .nyu.edu/leadership/religionandcivics.
} 
This experience helped convince me that for interfaith theological education to be maximally effective it must move beyond the academic classroom to include the people sitting in the pews. This inclusiveness not only avoids the rift between church and academy, it actually recruits and trains parishioners in deep Christian discipleship, equipping them for a life of faith in a religiously plural world.

\section{4}

\section{Conclusion}

Pentecostals' affective, transformational spirituality and theology, coupled with a philosophy of education driven by the same dynamic, is both an engine for interfaith education and an outcome of its pedagogical implementation. culture. Teaching and/or studying the theology of religions potentially enhances self-understanding, elicits deeper discipleship in Christ's service, increases mutual understanding and bridge-building potential with other religions, enables greater prospects for peaceful coexistence among diverse neighbors, and, finally, most of all, it evokes praise toward the Creator and God of all.

Nevertheless, Pentecostal connections with interreligious education and the interfaith movement are at best tenuous. Perennial concerns over relativistic religious pluralism mandate that interfaith education in a Pentecostal seminary or university consistently retain a strong sense of sectarian identity if it is to avoid opposition from within its own rank-and-file constituency. Commitment to one's own faith tradition does not necessarily disqualify one from interfaith relationship-building - provided there is respect for a parallel quality in others. Valued sectarian identity in tandem with respect for the identity of others invites interfaith relationships built on authenticity, transparency, and trust.

Evangelicals, and especially Pentecostals, have too long been invisible and unheard around interfaith education and dialogue tables. In part, we have no one to blame but ourselves-we simply have not sought a place at these tables. That is now changing.

\section{Bibliography}

Alvarez, Carmelo. "The Ecumenism of the Spirit: Emerging Contemporary Contexts of Mission in Latin America." In Miguel Alvarez, ed., Reshaping of Mission in Latin America, 174-93. Regnum Edinburgh Centenary 30. Eugene, OR: Wipf and Stock, 2016. 
Anderson, Allen. "Pentecostal and Charismatic Theology." In David F. Ford with Rachel Muers, eds., The Modern Theologians: An Introduction to Christian Theology since 1918, 601-603. Malden, MA: Blackwell Publishing, 2005.

Anderson, Norman. Christianity and World Religions: The Challenge of Pluralism, revised edition. Downers Grove, IL: InterVarsity Press, 1970, 1984.

Arrington, French L. Christian Doctrine: A Pentecostal Perspective. 3 vols. Cleveland, TN: Pathway Press, 1993.

Bales-Sherrod, Lesli. "Strangers of Differing Faiths Take a Seat at the Table and Leave as Friends." Knoxville News Sentinel, July 22, 1916. Accessed October 10, 2019. http:// archive.knoxnews.com/entertainment/life/strangers-of-differing-faiths-take-aseat-at-the-table-and-leave-as-friends-3827deco-9e6d-1074-e053--387954982.html.

Bebbington, David. Evangelicalism in Modern Britain: A History from the 1730 s to the 198os. New York: Routledge, 2002.

Chan, Simon. Spiritual Theology: A Systematic Study of the Christian Life. Downers Grove, IL: IVP Academic, 1998.

Denison, Jim. “Islam: Religion of Violence or Peace?” Denison Forum on Truth in Culture. May 23, 2017. Accessed October 10, 2019, http://assets.denisonforum.org/pdf/ Islam\%20a\%2oreligion\%20of\%2oviolence\%20or\%2opeace_pdf.

Denison, Jim. Radical Islam: What You Need to Know. Unlocking the Truth Series. Atlanta, GA: Elevation Press, 2011.

Faupel, William. The Everlasting Gospel: The Significance of Eschatology in the Development of Pentecostal Thought. Reprint. Journal of Pentecostal Theology Supplemental Series 10. Sheffield, UK: Sheffield Academic Press, 1996. Dorset, UK: Deo Publishing, 2009.

Fitzgerald, Frances. The Evangelicals: The Struggle to Reshape America. New York: Simon \& Schuster, 2017.

Gonzalez, Justo L. A History of Christian Thought in One Volume. Nashville, TN: Abingdon, 2014.

Grady, Lee J. Twenty-Five Tough Questions about Women and the Church: Answers from God's Word that will Set Women Free. Lake Mary, FL: Charisma House, 2003.

Han, Sang-Ehil, Paul Lewis Metzger, and Terry C. Muck, "Christian Hospitality and Pastoral Practices from an Evangelical Perspective." Theological Education 47, no. 1 (2012): 11-31.

Higton, Mike. A Theology of Higher Education. Oxford: Oxford University Press, 2012.

Hocken, Peter, Tony Richie, and Christopher A. Stephenson, eds. Christian Unity and Pentecostal Faith. Leiden, Netherlands: Brill, forthcoming.

Hofstadter, Richard. Anti-Intellectualism in American Life. Toronto, Canada: Random House, 1963.

Holman, Jo Ella. “We Make the Road by Walking': An Intercultural and Contextual Approach to Teaching and Learning." In Miguel Alvarez, ed. The Reshaping of Mission 
in Latin America, 221-234. Regnum Edinburgh Centenary Series 30. Oxford, UK: Regnum, 2015 .

Jenkins, Philip. The Next Christendom: The Coming of Global Christianity (The Future of Christianity Trilogy) 3rd ed. New York: Oxford University Press, 2011.

Johns, Cheryl Bridges. Pentecostal Formation: A Pedagogy among the Oppressed. Journal of Pentecostal Theology Supplement Series 2. Sheffield, UK: Sheffield Academic Press, 1993, 1998.

Johns, Jackie David. The Pedagogy of the Holy Spirit According to Early Christian Tradition. Cleveland, TN: CPM Press, 2012.

Juergensmeyer, Mark. Terror in the Mind of God: The Global Rise of Religious Violence. Berkeley and Los Angeles: University of California, 2001.

Kärkkäinen, Veli-Matti. An Introduction to the Theology of Religions: Biblical, Historical, and Contemporary Perspectives. Downers Grove, IL: InterVarsity Press, 2003.

Kärkkäinen, Veli-Matti. Christ and Reconciliation: A Constructive Christian Theology for the Pluralistic World. Grand Rapids, MI: Eerdmans, 2013.

Kärkkäinen, Veli-Matti. The Trinity and Religious Pluralism: The Doctrine of the Trinity in Christian Theology of Religions. Burlington, VT: Ashgate, 2004.

Kim, Sebastian and Kirsteen Kim, Christianity as a World Religion: An Introduction. 2nd ed. London/New York: Bloomsbury Academic, 2008, 2016.

King, J.H. From Passover to Pentecost 4th ed. Franklin Springs, GA: Advocate Press, 1911, 1976.

King, J.H. Christ_-God's Love Gift: Selected Writings of J. H. King, vol. 1. Franklin Springs, GA: Advocate Press, 1969.

Land, Steven Jack. Pentecostal Spirituality: A Passion for the Kingdom. Sheffield, UK: Sheffield Academic Press, 1993, 2010.

Macchia, Frank D. Baptized in the Spirit: A Global Pentecostal Theology. Grand Rapids, MI: Zondervan, 2006.

McCallum, Richard. "Islamophobia: A View from the UK." Evangelical Interfaith $\mathrm{Ob}$ server (Fall 2016): 32-33.

Mouw, Richard. Called to the Life of the Mind: Some Advice for Evangelical Scholars. Grand Rapids, MI: Eerdmans, 2014.

Neill, Stephen. Christianity and Other Faiths: Christian Dialogue with Other Religions. New York: Oxford University Press, 1961, 1970.

Netland, Harold. Encountering Religious Pluralism: The Challenge to Christian Faith \& Mission. Downers Grove, IL: InterVarsity Press, 2001.

Niebuhr, Reinhold. The Children of Light and The Children of Darkness: A Vindication of Democracy and A Critique of Its Traditional Defense. New York: Charles Scribner's Sons, 1944, 1960.

Orsborn, Catherine. "Standing Shoulder to Shoulder Against Anti-Muslim Bigotry." Evangelical Interfaith Observer (Fall 2016): 26-28. 
Parham, Charles F. The Sermons of Charles F. Parham. New York: Garland, 1985.

Pinnock, Clark H. Flame of Love: A Theology of the Holy Spirit (Downers Grove, IL InterVarsity Press, 1994).

Pinnock, Clark H. A Wideness in God's Mercy: The Finality of Jesus Christ in a World of Religions (Grand Rapids: Zondervan, 1992).

Richie, Tony. "Mr. Wesley and Mohammed: A Contemporary Inquiry Concerning Islam." Asbury Theological Journal 58, no. 2 (Fall 2003): 79-99.

Richie, Tony. "A Brief Response to Islamophobia by a Pentecostal Observer." Evangelical Interfaith Dialogue (Fall 2016): 40-41.

Richie, Tony. "A Politics of Pluralism in American Democracy: Reinhold Niebuhr's Christian Realism as a National Resource in a Post-9/11 World." Journal of Ecumenical Studies 45, no. 2 (Summer 2010): 471-92.

Richie, Tony. "Approaching Religious Truth in a Pluralistic World: A PentecostalCharismatic Contribution." Journal of Ecumenical Studies 43, no. 3 (Summer 2008): $35^{1-69 .}$

Richie, Tony. “Azusa-era Optimism: Bishop J. H. King's Pentecostal Theology of Religions as a Possible Paradigm for Today." In Veli-Matti Kärkkäinen, ed. The Spirit in the World: Emerging Pentecostal Theologies in Global Contexts, preface by Jürgen Moltmann, 227-44. Grand Rapids, MI: Eerdmans, 2009.

Richie, Tony. "Eschatological Inclusivism: Early Pentecostal Theology of Religions in Charles Fox Parham." Journal of the European Pentecostal Theological Association 27, no. 2 (2007): 138-42.

Richie, Tony. "Hints from Heaven: Can C. S. Lewis Help Evangelicals Hear God in Other Religions?” Evangelical Review of Theology 32, no. 1 (January 2008): 38-55.

Richie, Tony. "Neither Naïve nor Narrow: A Balanced Approach to Pentecostal Theology of Religions." Harold D. Hunter, ed., Cyberjournal for Pentecostal-Charismatic Research 15 (2006). Last Accessed October 12, 2019. http://www.pctii.org/cyberj/ cyberj15/richie.html.

Richie, Tony. "Revamping Pentecostal Evangelism: Appropriating Walter J. Hollenweger's Radical Proposal." International Review of Mission, 96 (July/October 2007): 343-54.

Richie, Tony. Speaking by the Spirit: A Pentecostal Model for Interreligious Dialogue. Asbury Seminary Series in World Christian Revitalization Movements in Pentecostal/ Charismatic Studies 6. Lexington, KY: Emeth Press, 2011.

Richie, Tony. Toward a Pentecostal Theology of Religions: Encountering Cornelius Today. Cleveland, TN: CPT Press, 2013.

Schleiermacher, Friedrich. Brief Outline of the Study of Theology (Edinburgh:T \& Clark, 1850).

Sugirtharajah, R. S. The Bible and the Third World: Precolonial, Colonial and Postcolonial Encounters. Cambridge: Cambridge University Press, 2001. 
Studebaker, Steven M. From Pentecost to the Triune God: A Pentecostal Trinitarian Theology. Grand Rapids, MI: Eerdmans, 2012.

Wariboko, Nimi and Amos Yong, eds. Paul Tillich and Pentecostal Theology: Spiritual Presence and Spiritual Power. Bloomington, IN: Indiana University Press, 2015.

Yong, Amos and Clifton Clarke, eds., Global Renewal, Religious Pluralism, and the Great Commission: Towards a Renewal Theology of Mission and Interreligious Encounter. Lexington, KY: Emeth Press, 2011.

Yong, Amos and Tony Richie. "Missiology and the Interreligious Encounter." In Allan Anderson, Michael Bergunder, André Droogers, and Cornelius Van Der Laan, eds., Studying Global Pentecostalism: Theories \& Methods, 245-67. Berkeley, CA: University of California Press, 2010.

Yong, Amos. Beyond the Impasse: Toward a Pneumatological Theology of Religions. Grand Rapids, MI: Baker, 2003.

Yong, Amos. Discerning the Spirit(s): A Pentecostal-Charismatic Contribution to Christian Theology of Religions. Sheffield, UK: Sheffield Academic Press, 2000.

Yong, Amos. Hospitality and the Other: Pentecost, Christian Practices, and the Neighbor. Maryknoll, NY: Orbis, 2008.

Yong, Amos. Pneumatology and the Christian-Buddhist Dialogue: Does the Spirit Blow through the Middle Way? Leiden and Boston: Brill, 2012.

Yong, Amos. The Spirit Poured Out on All Flesh: Pentecostalism and the Possibility of Global Theology. Grand Rapids, MI: Baker, 2005. 